\title{
EFFECT OF VOLCANIC ASH AS PARTIAL REPLACEMENT OF CEMENT IN CONCRETE SUBJECT TO AGGRESSIVE CHEMICAL ENVIRONEMNT
}

\author{
Agboola Shamsudeen Abdulazeez ${ }^{1}$, Amina Omolola Suleiman ${ }^{2}$, Simdima Gabriel Gideon ${ }^{3}$, Solomon \\ Wutong Poki ${ }^{4}$ \\ ${ }^{1 \& 2}$ M.Tech Student, Abubakar Tafawa Balewa University Bauchi, Nigeria \\ ${ }^{3}$ Maintenance Department Federal Character Commission Abuja, Nigeria \\ ${ }^{4}$ Tehsow Construction Ltd. Plateau, Nigeria
}

\begin{abstract}
Presently researches all over the world is concentrating on alternative materials as partial cement replacement in concrete production. The use of pozzolanic material in concrete is becoming increasingly important because of the need for more sustainable cementing products. Volcanic ash is a form of natural pozzolan and has a chemical composition comparable to other supplementary cementitious materials. In this paper, volcanic ash was used to partially replace cement in the ratio of $0 \%, 5 \%, 10 \%, 15 \%$ and $20 \%$ by volume in concrete and cured in $\mathrm{H}_{2} \mathrm{SO}_{4}$ and $\mathrm{MgSO}_{4}$ environment. 28-day target strength was adopted and concrete tested at 7, 14, 28 and 56 days' hydration period. Specific gravity, bulk density and setting time test on volcanic ash were carried out. Fresh concrete tests such as slump and compacting factor test were carried out along-side hardened concrete tests like compressive strength and split tensile strength. The result shows that the maximum compressive strength at 28 days was at $0 \%$ control concrete, while at 56 days the maximum strength was observed at $10 \%$ replacement of cement with volcanic ash and it is considered as optimum percentage replacement.
\end{abstract}

Key words: Compressive strength, split tensile strength, magnesium sulphate, tetra-oxo sulphate (vi) acid, Volcanic ash, ordinary Portland cement, specific gravity, bulk density, void ratio, setting time, consistency.

\section{INTRODUCTION}

Concrete is still the most extensively used construction material, it is versatile in nature and application. Concrete as the most utilized number one structural material is a composite mixture of cement, aggregate, water and admixture. With the global pandemic issues coupled with the imbalance in market trends in terms of cost, the materials used in the production of building and structures has been on the increase, therefore leading high cost of construction as a whole, and the general practice in the practice of building and civil engineering construction largely depend on conventional construction material to a large extent. Reduction in the overdependence on conventional material used in manufacture of building and structural element is presently the trend in the field of construction by resulting to alternative construction material. Also concrete as a versatile material and an important construction material over the world have great impact on the environment. Cement is unarguable an important material in the production of concrete. Cement which is the binder in concrete and one major component and key ingredient in the production of concrete have impact on the environment. Manufacturing of cement is a major source of greenhouse gas emissions [1]. The billions of tons of raw materials of cement mined and processed each year leave a mark on the environment. During the production of Portland cement great amount of energy is required and large quantities of $\mathrm{CO}_{2}$ is produced and released into the atmosphere. The growing concern of resource depletion and global pollution has led to researches to develop alternative material in construction. The use of supplementary cementitious materials (SCMs) to offset a portion of the cement in concrete is a promising method for reducing the environmental impact of producing cement from the industry. The development of supplementary cementitious materials (SCMs) is said to be fundamental not to only in terms of low-cost but also to improving concrete properties. The main benefits of SCMs include saving natural resources and energy as well as protecting the environment through 


\section{International Journal of Engineering Applied Sciences and Technology, 2021 Vol. 6, Issue 5, ISSN No. 2455-2143, Pages 100-108 \\ Published Online September 2021 in IJEAST (http://www.ijeast.com)}

the use of these main admixtures [2]. The use of supplementary cementitious materials (SCMs) to offset a portion of the cement in concrete is a promising method for reducing the environmental impact from the industry. Several industrial byproducts have been used successfully as SCMs, including silica fume (SF), ground granulated blast furnace slag (GGBS) and fly ash [3]; also natural occurring materials such as volcanic ash have also been used successfully as SCMs [4]. Another material which has potential as a SCM, however, has not yet achieved the same commercial success is waste glass [5-6]. Supplementary cementitious material and or pozzolans are used to improve strength and certain durability properties of concrete.

According to [7] the use of pozzolan to replace OPC in concrete lower heat development during hardening and improve durability of the final concrete structures. Among the pozzolans used in concrete, volcanic ash has been identified as having potential for use as partial replacement of cement in the production of concrete. Volcanic ash is a form of natural pozzolan and has a chemical composition comparable to others SCMs [4]. Natural pozzolans include; clay and shales, opalinc cherts, diatomaceous earth, volcanic ash, volcanic tuffs and pumicites, Artificial pozzolans include; fly ash, blast furnace slag, silica fume, rice husk ash, metakaoline and surkhi. Volcanic ash, being one of the classifications of natural pozzolans, is environmentally friendly, economical and accessible. According to [2], volcanic rock is formed as a result of volcanic eruption which can be found in volcanic areas around the world e.g. Japan, USA, Iranian plateau, Adamawa highlands extending to Cameroonian highlands. [4] carried out research on natural pozzolan (volcanic ash) to replace ordinary Portland cement (OPC) in concrete, the result showed that the material can be used to partially replace ordinary Portland cement. This can lead to reactions between major constituents of Portland cement and that of the volcanic ash known as pozzolanic reaction. Pozzolanic reactions are silica reactions that take place in the presence of calcium hydroxide and water to produce calcium silicate hydrates(C-S-H). This calcium silicate hydrate creates a denser microstructure that increases strength, reduces the permeability of concrete and improves its resistance to chemical attack [8]. [4] carried out a research on volcanic ash and the results showed that volcanic ash possessed pozzolanic characteristics of natural pozzolans and recommend that it can be used to partially replace cement in concrete. These materials are used to create blended cements which can improve concrete durability, early and long term strength, workability and economy [9].
Concrete structures are built in highly polluted urban and industrial areas, aggressive marine environments and many other hostile conditions where materials of construction are found to be non-durable. Aggressive chemical environment is an environment with the presence of chemicals such as acid, salt water which affects the properties of concrete. When a concrete member is exposed to harsh environment area, the surrounding environmental factors can affect concrete durability. This environmental factors cause several types of deterioration in concrete. In most of the cases, the concrete degradation process involves the penetration and subsequent movement of water, air, or other fluids which are transporting aggressive agents into concrete pore system [10]. According to [7] use of pozzolan to replace OPC in concrete lower heat development during hardening and improve durability of the final concrete structures. Concrete can be proportionally made strong but not durable. [11] considered long service life as synonymous with durability and further stated that durability of concrete is the ability to perform satisfactorily in the exposure condition to which it's subjected to, over an intended period of time with minimum of maintenance. [12] stated that in the past, concrete researchers and designers paid too much attention on compressive strength neglecting other properties of concrete like durability.

One of the most important aspects of durability which is of concern is chemical attack which results in volume change, cracking of concrete and the consequent deterioration of concrete. However, it has now been recognized that compressive strength of concrete alone is not sufficient to judge the quality of concrete, the degree of aggressiveness of the environment to which the concrete is subjected to, is equally important to look upon. Consequently, both strength and durability have to be considered thoroughly at both the research and design stage [12]. Therefore, this study aims to investigate the effect of volcanic ash as partial replacement of cement in concrete subject aggressive chemical environment.

\section{EXPERIMENTAL PROGRAM}

\subsection{Materials}

Materials used in carrying out this research activity include cement (CEM 1 of strength grade 42.5R). The percentage of clinker and gypsum in the cement was 95-100\% and $0-5 \%$ respectively, while the specific gravity of OPC was found to be 3.15 according to [13], fine aggregate, coarse aggregate, water and volcanic ash. Ordinary Portland cements obtained from the cement vendors was used. Locally available clean river sand passing from $4.75 \mathrm{~mm}$ sieve free from 


\section{International Journal of Engineering Applied Sciences and Technology, 2021 Vol. 6, Issue 5, ISSN No. 2455-2143, Pages 100-108 \\ Published Online September 2021 in IJEAST (http://www.ijeast.com)}

inorganic materials was used. Coarse aggregate having maximum size of $20 \mathrm{~mm}$ clean and free from clay and other ingredients was used in the preparation of concrete mix. Volcanic ash was grinded and passed through sieve $75 \mu \mathrm{m}$ before using it as cement replacement material.

\subsection{Mix Proportions}

Total 180 specimens were cast for cubes and cylinder produced with cement, fine aggregate and coarse aggregate and volcanic ash using a design mix of 1:2:4 and a water binder ratio of 0.5 for all batches. Dimensions of specimens were $100 \times 100 \times 100 \mathrm{~mm}$ for cubes and cylinder specimen of $150 \mathrm{~mm}$ diameter and height equal to $300 \mathrm{~mm}$. One mixture of plain concrete and four other mixture of concrete prepared with $5 \%$, $10 \%, 15 \%$ and $20 \%$ replacement of cement with volcanic ash.

\subsection{Testing Methodology}

Workability and density of hardened concrete of all mixtures were determined as per [14] and [15] respectively. Compressive and split tensile strength was conducted on the specimen of plain concrete, and concrete prepared with substitution of cement by different proportions of volcanic ash of $0 \%, 5 \%, 10 \%$, $15 \%$ and $20 \%$, at a curing age of 7 days, 14 days, 28 days and 56 days for compressive strength while test was conducted for tensile strength at 28 days and 56 days as per [16] and [17] respectively.

\subsection{Curing Media}

Two types of curing medium were used which included; $1.2 \%$ concentration of $\mathrm{H}_{2} \mathrm{SO}_{4}$ and $1.2 \%$ concentration of $\mathrm{MgSO}_{4} .1 .2 \%$ concentration of $\mathrm{MgSO}_{4}$ and $\mathrm{H}_{2} \mathrm{SO}_{4}$ used for this research were severe concentration range as indicated by [18]. A bowl that has the capacity up to 200 liters of water was used to cure concrete samples, but only 100 liters of water was poured. This was done to allow the specimens to be placed and cured properly without overflow. The calculation was done in this way:

100 liters of water is equivalent to $100,000 \mathrm{~g}$ by weight $100,000 \mathrm{~g}$ of water to $100 \%$ concentration of chemical Unknown gram of water to $1.2 \%$ concentration of chemical, therefore mathematically:

$50000=100 \%$

$\mathrm{x}=1.2 \%$

$\mathrm{x}=\frac{100,000 \times 1.2}{100}=1200 \mathrm{~g}-\ldots$

\subsection{Specific Gravity}

Specific gravity of volcanic ash was determined using the procedure in accordance with [19]. The apparatus used during the test include density bottle and stopper, funnel, spatula and weighing balance.

The specific gravity of aggregates was calculated using equation (2)

$\mathrm{Gs}=\frac{M 2-M 1}{(M 4-M 1)(M 3-M 2)}=\ldots$
Where: $M_{1}$ is the weight of empty cylinder $\mathrm{M}_{2}$ is the weight of empty cylinder plus sample $\mathrm{M}_{3}$ is the weight of empty cylinder plus water plus sample

$\mathrm{M}_{4}$ is the weight of empty cylinder plus water

2.6 Bulk Density and Voids

The test was carried out in accordance with [20]. The bulk density of aggregates was calculated using equation 3 .

$\mathrm{D}=\frac{M}{V}=-\quad-\quad-\quad-\quad-\quad-\quad-\quad-\quad-\quad-(3)$

Where $\mathrm{D}$ is the density of the specimen in $\mathrm{kg} / \mathrm{m}^{3}$

$\mathrm{M}$ is the mass of the specimen in $\mathrm{kg}$

$\mathrm{V}$ is the volume of the specimen in $\mathrm{m}^{3}$

Also mass of the sample was determined by subtracting the weight of empty container from the weight of container plus sample using equation 4 .

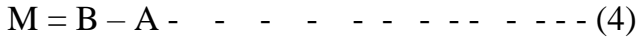

Where $M$ is the mass of the aggregate specimen in $\mathrm{kg}$ $\mathrm{A}$ is the weight of the empty container in $\mathrm{kg}$ $\mathrm{B}$ is the weight of container plus sample in $\mathrm{kg}$ While percentage void was calculated using equation 5

$\rho=\frac{\text { weight of compacted VA }- \text { weight of uncompacted VA }}{\text { weight of uncompacted of VA }}-$ -

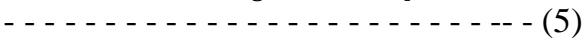

2.7 Setting Time Test

Setting time test and consistency was conducted in accordance with [21]. Initial setting time and final setting time were carried out using Vicat apparatus with the plunger and needle. Five different mixes with $0 \%, 5 \%, 10 \%, 15 \%$ and $20 \%$ replacement of Portland cement with volcanic ash paste was prepared for setting time test. However, Consistency was determined using equation 6

Consistency $=\frac{\text { water consumed }}{\text { weight of cement cement sample }} \times 100 \%$ - (6)

\section{RESULTS AND DISCUSSION}

\subsection{Specific Gravity}

Value obtained for specific gravity of volcanic ash as presented in Table 1 is 3.28.

\subsection{Bulk Density}

Values obtained for compacted and un-compacted bulk for volcanic ash as presented in Table 2 were 1703 and 1499 respectively, while the percentage void of volcanic ash is $13.61 \%$.

\subsection{Workability}

The results of all the 5 mixtures of the workability of control concrete specimen and concrete prepared as partial replacement of cement with volcanic ash is presented in Figure 1 and 2. The result shows that the workability of concrete increases as the cement replacement with volcanic ash increases. The 


\section{International Journal of Engineering Applied Sciences and Technology, 2021 \\ Vol. 6, Issue 5, ISSN No. 2455-2143, Pages 100-108 \\ Published Online September 2021 in IJEAST (http://www.ijeast.com)}

maximum increase in workability was observed at $20 \%$ replacement of cement with volcanic ash.

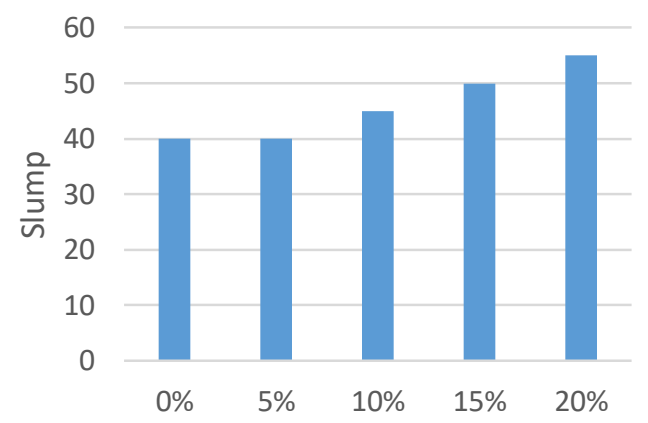

Percentage replacement of cement with VA

Figure 1: Slump Test Value

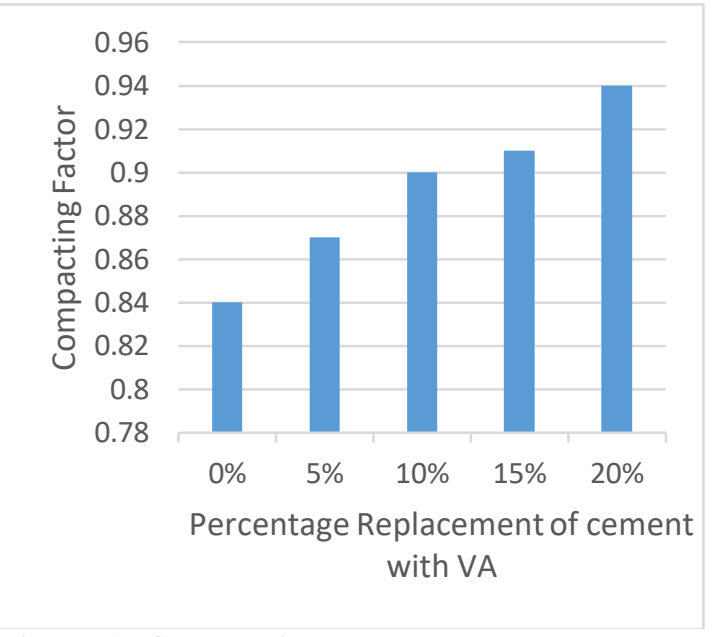

Figure 2: Compacting Factor Test Value

\subsection{Setting Time}

Values obtained as initial setting time for OPC and OPC/VA pastes at different percentages of $0 \%, 5 \%$, $10 \%, 15 \%$ and $20 \%$ were 47 minutes, 55 minutes, 1hour 5minutes, 1 hour 5minutes and 1 hour 15 minutes respectively. Final setting time values were obtained for OPC and OPC/VA pastes as 4 hours 22 minutes, 4 hours 50 minutes, 4 hours 55 minutes, 5 hours 45 minutes and 6 hours 30 minutes. The result is presented in Figure 3.

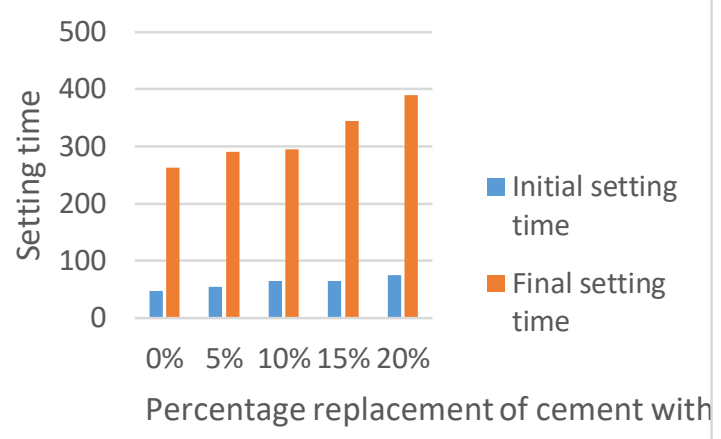
VA

Figure 3: Setting Time Test

\subsection{Consistency}

Percentage consistency obtained for OPC and OPC/VA pastes at different percentages of $0 \%, 5 \%$, $10 \%, 15 \%$ and $20 \%$ were $27.25 \%, 28.75 \%, 29.5 \%$, $29.5 \%$ and $30.25 \%$. The result is presented in Figure 4.

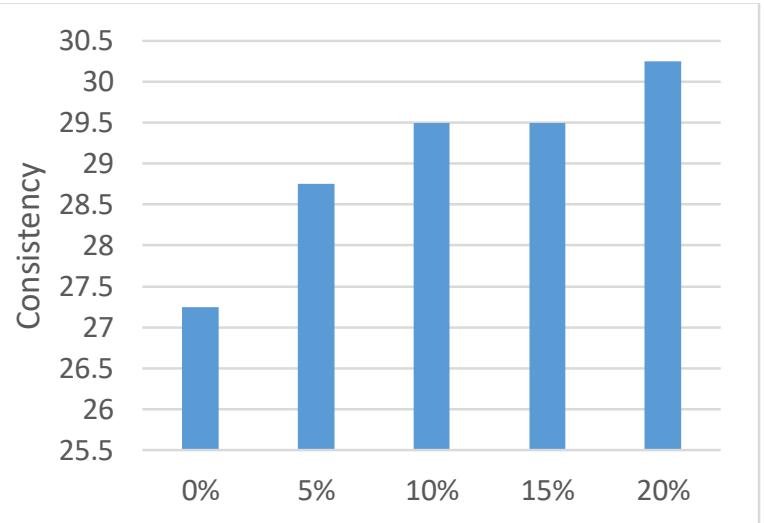

Percentage replacement of cement with V/

\section{Figure 4: Consistency Value}

\subsection{Density of Hardened concrete}

The results of all the 5 mixtures of density of control concrete and concrete prepared with volcanic ash as partial replacement of cement is presented in Figure 58 . The result shows that control concrete has increased density above all other concrete using volcanic ash as partial replacement of cement at 28 days, beyond 28days density of concrete partially replaced with volcanic ash up-to $15 \%$ shows increased density. Also the density of hardened concrete is increased with volcanic partially replacing cement from (5\%-15\%). The maximum density at 28 days of concrete specimen in $\mathrm{H}_{2} \mathrm{SO}_{4}$ curing media was at $0 \%, 10 \%$ and $15 \%$, these shows that the density of concrete partially replaced with volcanic ash is comparable to that of control concrete cured in $\mathrm{H}_{2} \mathrm{SO}_{4}$ environment. Also the maximum density of specimen cured in $\mathrm{H}_{2} \mathrm{SO}_{4}$ at 56 


\section{International Journal of Engineering Applied Sciences and Technology, 2021 \\ Vol. 6, Issue 5, ISSN No. 2455-2143, Pages 100-108 \\ Published Online September 2021 in IJEAST (http://www.ijeast.com)}

days was observed to be at $10 \%$ and $15 \%$ partial replacement of cement with volcanic ash. The result shows same density for concrete with $10 \%$ and $15 \%$ partial replacement of cement with volcanic but shows an increase in density of $1.39 \%$ as compared to control concrete. Furthermore, the result for concrete cured in $\mathrm{MgSO}_{4}$ solution and at 28days curing period shows same density for concrete produced with $10 \%$ replacement of cement with volcanic ash and that of control concrete. There is an increase of $0.60 \%$ of concrete produced with $10 \%$ and $15 \%$ volcanic ash as partial replacement of cement as compared to control concrete specimen cured in $\mathrm{MgSO}_{4}$ medium at 56 days. On further note the density of concrete at $0 \%$, $10 \%$ and $15 \%$, shows higher value at all curing ages. While density of cylindrical specimen shows that $10 \%$ and $15 \%$ have same density and also shows that they have an increase in density of $0.20 \%$ as compared to that of the control specimen at 28days in $\mathrm{H}_{2} \mathrm{SO}_{4}$ curing environment, while at 56 days for concrete cured in $\mathrm{H}_{2} \mathrm{SO}_{4}$ environment, $15 \%$ volcanic ash as partial replacement of cement shows maximum density and it has an increase in density of $0.79 \%$ as compared to the control concrete specimen. The density of cylindrical specimen at 28days curing in $\mathrm{MgSO}_{4}$ environmental condition shows higher density for the control concrete as compared to other percentage replacement of cement with volcanic ash, while at 56 days, partial replacement of cement with $15 \%$ volcanic ash shows higher density than the control specimen. The result shows that volcanic ash has significant influence on the properties of concrete. In addition, replacement of cement more than $15 \%$ with volcanic ash showed reduced density for both cube and cylindrical specimen cured in $\mathrm{H}_{2} \mathrm{SO}_{4}$ and $\mathrm{MgSO}_{4}$ environment.

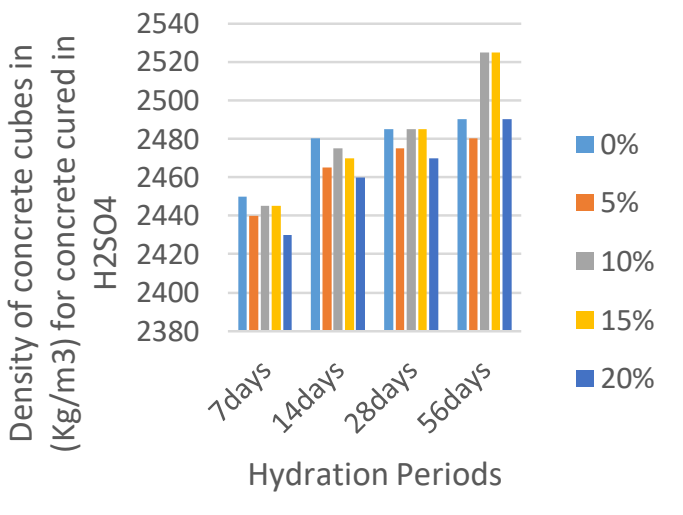

Figure 5: Density of Cubes in $\mathrm{H}_{2} \mathrm{SO}_{4}$

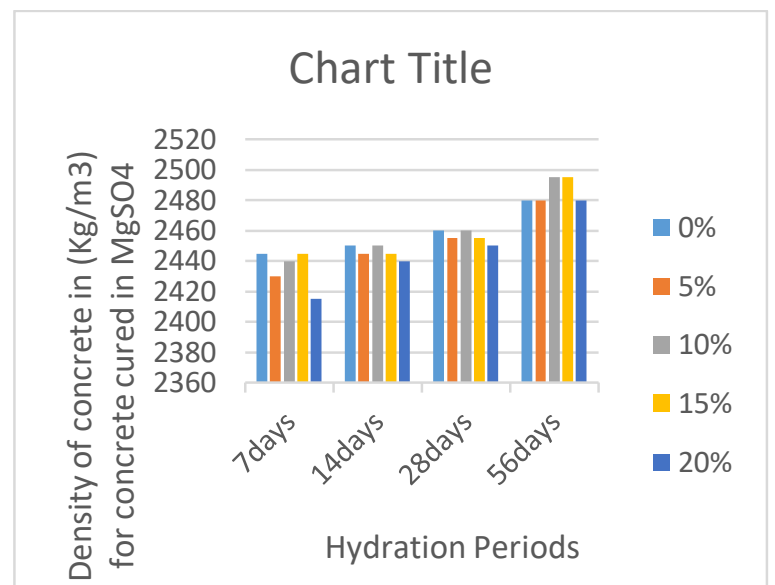

Figure 6: Density of Cubes in $\mathrm{MgSO}_{4}$

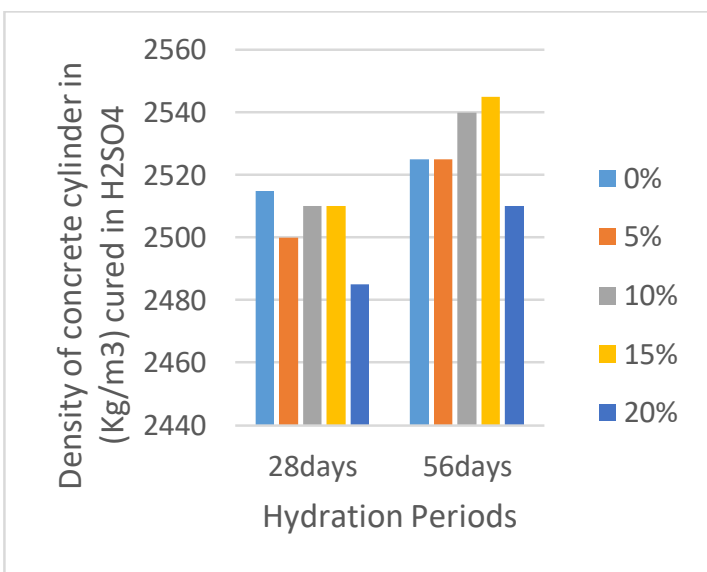

Figure 7: Density of Cubes in $\mathrm{H}_{2} \mathrm{SO}_{4}$

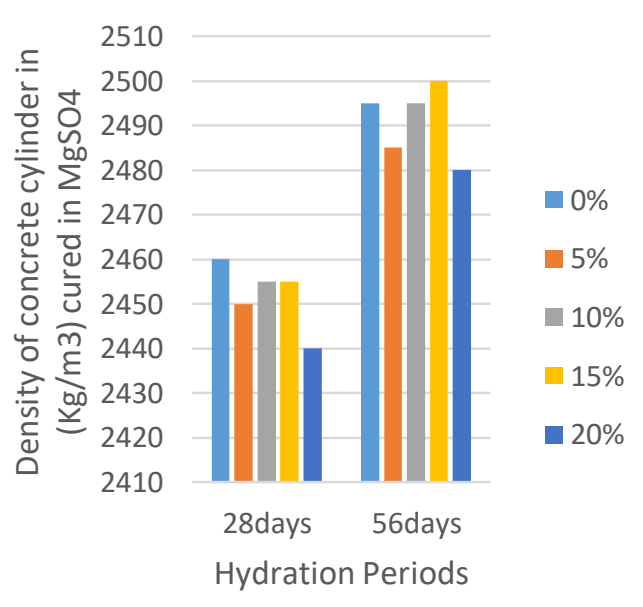

Figure 8: Density of Cubes in $\mathrm{MgSO}_{4}$

\subsection{Compressive strength}

The results of compressive strength of control concrete and concrete prepared with partial replacement of 


\section{International Journal of Engineering Applied Sciences and Technology, 2021 \\ Vol. 6, Issue 5, ISSN No. 2455-2143, Pages 100-108 \\ Published Online September 2021 in IJEAST (http://www.ijeast.com)}

cement with volcanic ash of all 5 mixes are shown in Figure 9 and Figure 10. The maximum compressive strength of concrete cured in $\mathrm{H}_{2} \mathrm{SO}_{4}$ solution at 28 days was observed at $0 \%$ control concrete specimen which is above all percentage replacement of cement with volcanic ash. While at 56 days the maximum strength was observed at $10 \%$ replacement of cement in concrete with volcanic ash which shows an increase of $2.25 \%$ as compared to control concrete specimen. In $\mathrm{MgSO}_{4}$ solution, the maximum strength at 28 days of curing was observed at $0 \%$ control concrete which shows an increase in strength over all other cement replacement in the concrete mixes. At 56 days curing age in $\mathrm{MgSO}_{4}$ environmental conditions, the maximum strength was observed at $10 \%$ replacement of cement with volcanic ash with an increase of $1.23 \%$ as compared to that of control concrete, while $15 \%$ percentage replacement of cement with volcanic ash exhibit same strength index with the control concrete. From the result of the study, it can be deduced that volcanic ash as a pozzolanic material has effect on concrete properties at higher curing age above 28 days. On further note, $\mathrm{MgSO}_{4}$ environment has deteriorative effect on concrete properties more than $\mathrm{H}_{2} \mathrm{SO}_{4}$. However, replacement of cement more than $15 \%$ with volcanic ash shows decrease in the compressive strength of concrete. This current study at 56 days shows $10 \%$ cement replacement level gave the greatest compressive strength in concrete. However, this means as the curing age increase the strength of concrete produced with volcanic ash as partial replacement of cement to $15 \%$ replacement level is increased.

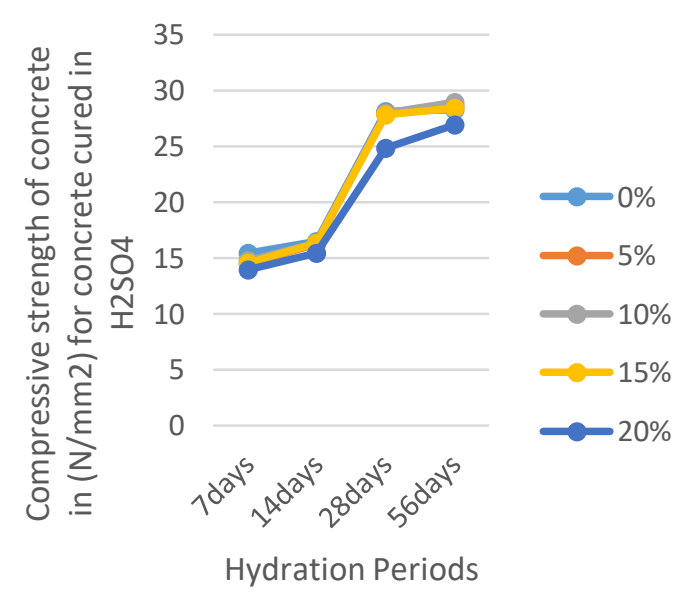

Figure 9: Compressive Strength of Concrete cured in $\mathrm{H}_{2} \mathrm{SO}_{4}$

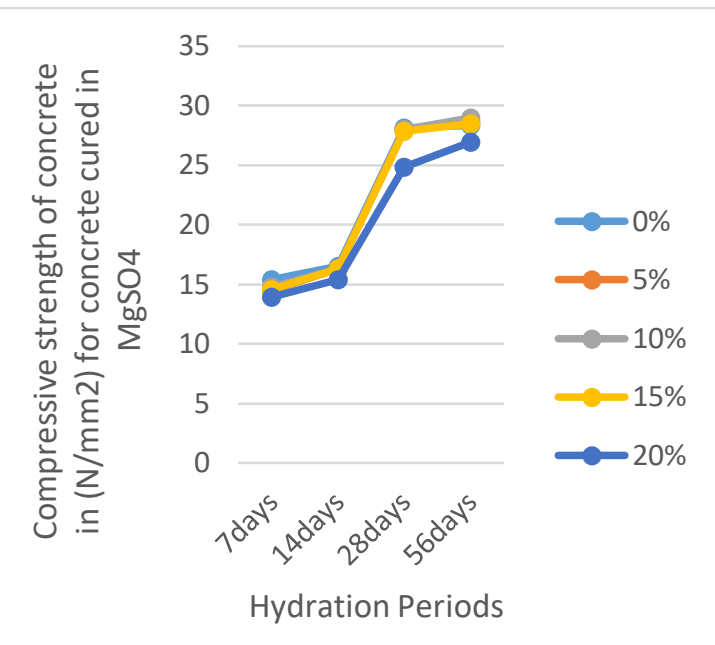

Figure 10: Compressive Strength of Concrete cured in $\mathrm{MgSO}_{4}$

\subsection{Tensile strength}

The results of tensile strength of control concrete and concrete prepared with partial replacement of cement with volcanic ash of all the 5 mixes are presented in Figure 11 and 12. The maximum tensile strength of concrete cured in $\mathrm{H}_{2} \mathrm{SO}_{4}$ solution at 28 days was observed at $0 \%$ control concrete specimen which is above all percentage replacement with volcanic ash. While at 56 days the maximum strength was observed at $10 \%$ replacement of cement in concrete with volcanic ash which shows an increase of $4.32 \%$ as compared to control concrete specimen. While in $\mathrm{MgSO}_{4}$ solution, the maximum strength was observed at $0 \%$ control concrete which shows an increase in strength over all other cement replacement level in the concrete mixes. At 56 days curing age in $\mathrm{MgSO}_{4}$ environmental conditions, the maximum strength was observed at $10 \%$ replacement of cement with volcanic ash which shows an increase of $2.37 \%$ as compared to that of control concrete. However, replacement of cement more than $15 \%$ replacement level with volcanic ash shows decrease in the tensile strength of concrete. 


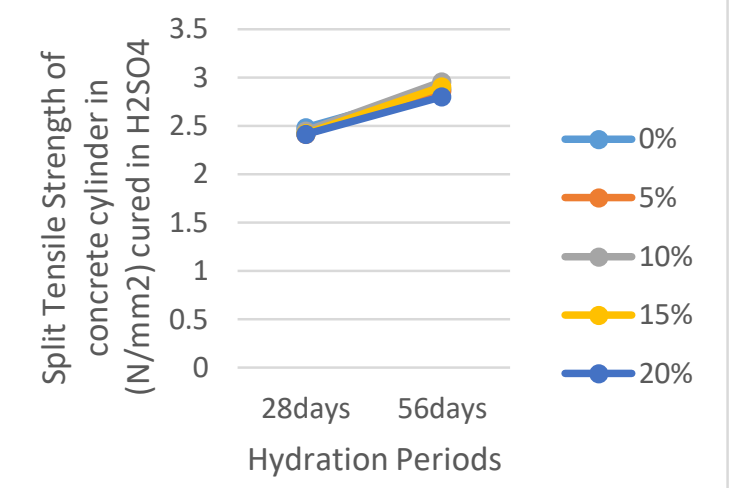

Figure 11: Split Tensile Strength of Concrete cured in $\mathrm{H}_{2} \mathrm{SO}_{4}$

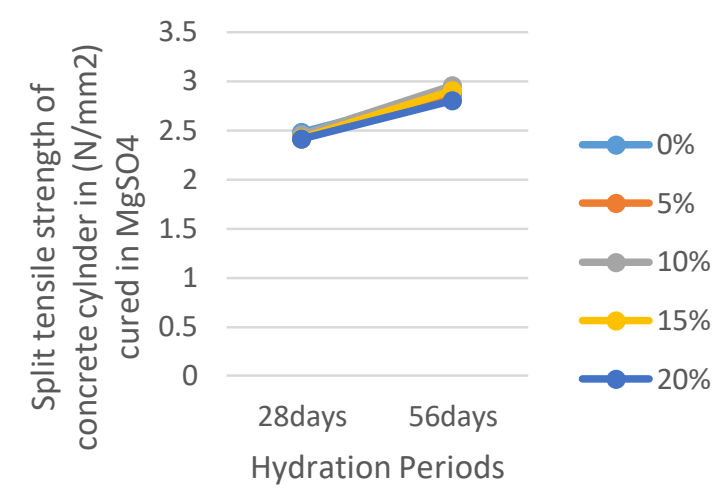

Figure 12: Split Tensile Strength of Concrete cured in $\mathrm{MgSO}_{4}$

Table 1: Specific Gravity Test on Volcanic Ash

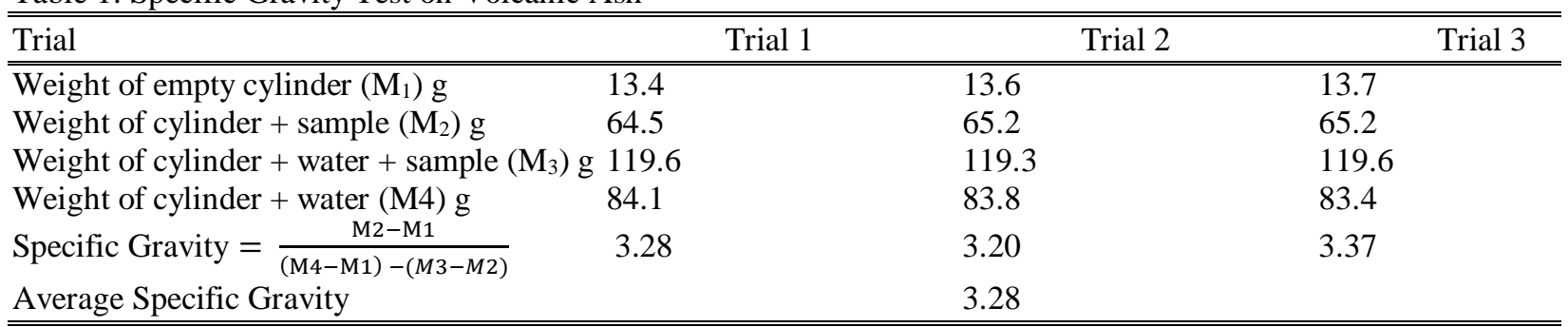

Table 2: Bulk Density for Volcanic Ash

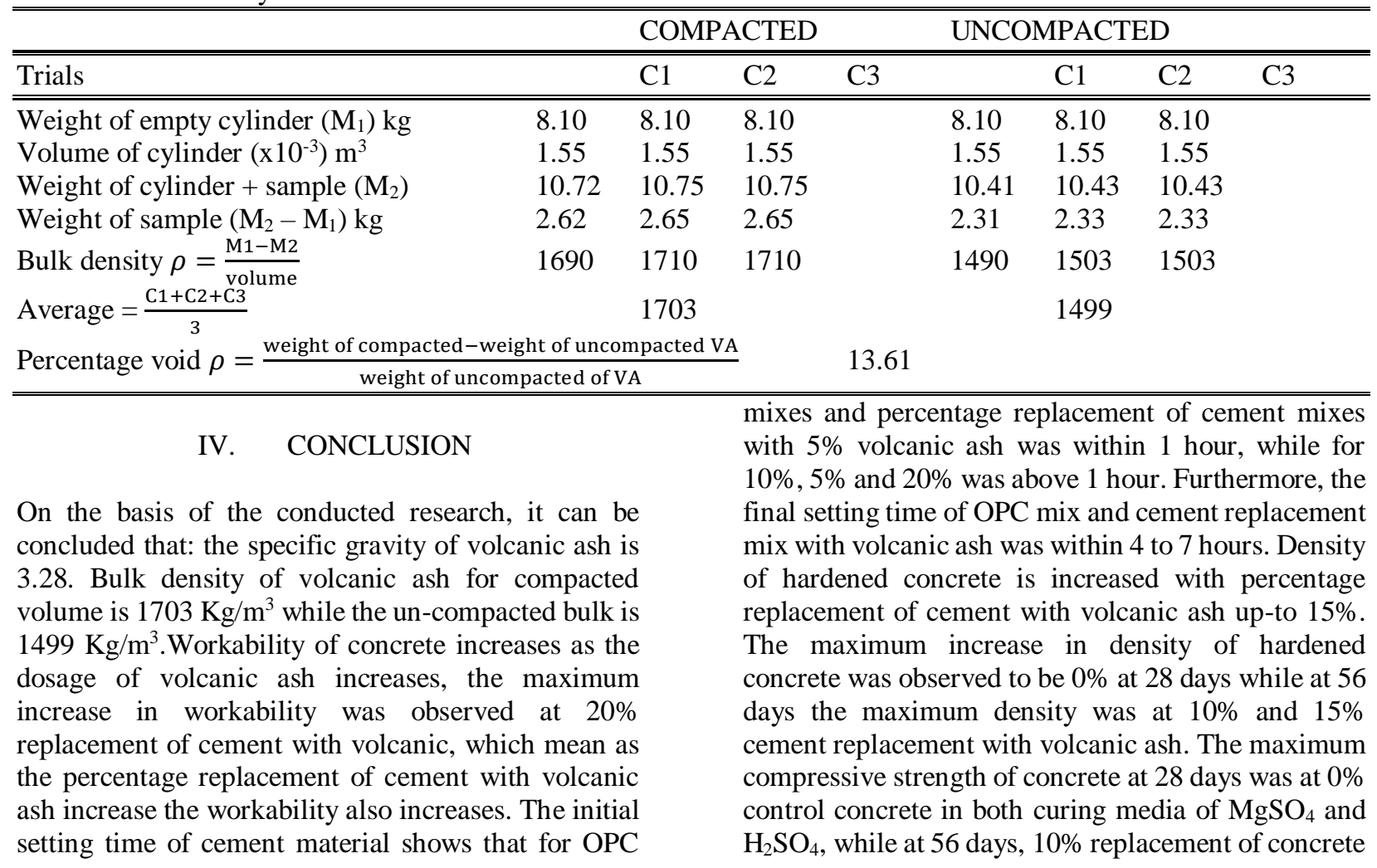




\section{International Journal of Engineering Applied Sciences and Technology, 2021 Vol. 6, Issue 5, ISSN No. 2455-2143, Pages 100-108 \\ Published Online September 2021 in IJEAST (http://www.ijeast.com)}

with volcanic ash gave maximum strength in both curing media of $\mathrm{MgSO}_{4}$ and $\mathrm{H}_{2} \mathrm{SO}_{4}$. The maximum split tensile strength of concrete at 28 days was observed at $0 \%$ control concrete, which was above all other replacement level with volcanic ash. At 56 days curing, the maximum tensile strength of concrete was observed at $10 \%$ replacement of cement with volcanic ash in both curing media. The production of volcanic ash for concrete production results in the reduction of $\mathrm{CO}_{2}$ emission from cement production and save the environment significantly by reducing green-house gas and particulate production. Hence, on the bases of the results, $10 \%$ replacement of cement with volcanic ash is optimum. However, further research on microstructural characterization aspect and other durability properties of volcanic ash as partial replacement of cement in concrete is required for sustainable concrete construction practice.

\section{REFERENCES}

1. Imbabi. S.M., Carrigan. C. and Mckenna S. (2012). "Treand and Developments in Grean Cement and Concrete Technology", International Journal of Sustainable Built Environment.1(2), 194-216.

2. Ogunbode, E. B. and Hassan, I. O. (2011). Effect of Addition of Calcium Nitrate on Selected Properties of Concrete Containing Volcanic Ash. Leonardo Electronic Journal of Practice and Technologies, 29-38. Retrieved Date: January 16, 2019, from http://www.lejpt.academicdirect.org.

3. Islam, G.M.S., Islam, M.M., Akter, A., Islam, M.S., 2011. Green construction materialsBangladesh perspective. In: Proceedings of the International Conference on Mechanical Engineering and Renewable Energy 2011, (ICMERE2011) 22-24 December 2011, Chittagong, Bangladesh (ID-063).

4. Agboola S.A., Mamman A.I., Tapgun J., and Bappah H. (2020). Strength Performance of Concrete Produced with Volcanic Ash as Partial Replacement of Cement. International Journal of Engineering Research and Technology (IJERT). Vol. 9, Issue 03, Pp. 372 -378, ISSN: 2278-0181. March 2020.

5. Rashed, A.M., 2014. Recycled waste glass as fine aggregate replacement in cementitious materials based on Portland cement. Constr. Build. Mater. 72, 340-357.

6. Agboola S.A., Mamman A.I., Musa A.K., and Bappah H. (2020). Effect of Waste Glass Powder as a Pozzolanic Material in Concrete Production. International Journal of
Engineering Research and Technology (IJERT). Vol. 9, Issue 02, Pp. 589 - 594, ISSN: 2278-0181. February 2020.

7. Joergensen, S. W. (2014). Grinding of Clinker Replacement Materials. Special Report by General Manager Grinding Technology, 1-15.

8. Osei, D. Y. and Jackson, E. N. (2012). Compressive Strength and Workability of Concrete Using Natural Pozzolan as Partial Replacement of Ordinary Portland Cement. Journal of Advances in Applied Science Research, 3(6), 3658-3662. Retrieved from http://www.pelagiaresearchlibrary.com.

9. Detwiler, R., Bhatty, J.I. and Bhattacharja, S. (1996). Supplementary Cementing Materials for Use in Blended Cements. Research and Development Bulletin Rd112t, Portland Cement Association, Skokie, Illinois, USA.

10. Bryant J. W., Weyers R. E., and Garza J. M. (2009). In-Place Resistivity of Bridge Deck Concrete Mixtures, ACI Materials Journal, 106(2), 114-122.

11. Nagesh, M. (2012). Notes on Concrete Durability. Unpublished Lecture Note. Government Engineering College Ramanagara, India.

12. Shetty, M. S. (2009). Concrete Technology; Theory and Practice, S Chad and Company, New Delhi, India, 174-418.

13. ASTM C786, 2016d. Standard Test Method for Fineness of Hydraulic Cement and Raw Materials by the $300-1 \mathrm{~m}$ (No. 50), 150-1m (No. 100), and 75-lm (No. 200) Sieves by Wet Methods. ASTM International, West Conshohocken, USA.

14. ASTM C143, 2005. "Standard Test Method for Slump of Hydraulic - Cement Concrete".

15. British Standard European Norm, (2000). Testing hardened concrete; Density of hardened concrete. BS EN 12390-7, BSI, Linfordwood, Milton Keynes MK14 6LE, U.K.

16. British Standards Institution, BS 1881: Part 116 (1983) Method for determination of Compressive Strength of Concrete Cubes. London, BSI.

17. British Standard European Norm, (2009). Testing hardened concrete; Tensile splitting strength of test specimen. BS EN 12390-7, BSI, Linfordwood, Milton Keynes MK14 6LE, U.K.

18. Monteiro, P. J. M. (Anonymous). Durability. Unpublished Lecture Note. Department of 
International Journal of Engineering Applied Sciences and Technology, 2021

Vol. 6, Issue 5, ISSN No. 2455-2143, Pages 100-108

Published Online September 2021 in IJEAST (http://www.ijeast.com)

Civil Engineering University of California Berkeley USA.

19. British Standard, (1995). Testing aggregates; Methods of determination of density. BS 8122, BSI, Linfordwood, Milton Keynes MK14 6LE, U.K.

20. British Standard, (1975). Testing aggregates; Methods of determination of particle size and shape. BS 812-1, BSI, Linfordwood, Milton Keynes MK14 6LE, U.K.

21. British Standard European Norm, (1995). Methods of testing cement; Determination of setting time and soundness. BS EN 196-3, BSI, Linfordwood, Milton Keynes MK14 6LE, U.K. 